\title{
FORMATION OF THE ORGANIZATIONAL AND FUNCTIONAL MODEL OF INNOVATIVE TRANSFORMATION OF TRANSPORT AND LOGISTICS SYSTEMS
}

\author{
Inna Irtyshcheva', Sergii Voit' ${ }^{2}$, Anatoly Nosar ${ }^{3}$
}

\begin{abstract}
The subject of the study is the theoretical and methodological aspects of the formation of organizational and functional model of innovative transformation of transport and logistics systems. Methodology. General scientific methods used in the study, in particular: theoretical generalization; methods of positive and normative analysis, statistical analysis. The purpose of the study is to substantiate the formation of the organizational and functional model of innovative transformation of transport and logistics systems. Results. The article provides a basis for the formation of organizational and functional model of innovative transformation of transport and logistics systems. The substantive and critical characteristics of the development of transport and logistics systems are investigated. The main factors and motives for the functioning of warehouse logistics in Ukraine were revealed. The main factors and reasons for the development of warehouse logistics in Ukraine were revealed. It has been proved that the reasons and factors for the development of logistics in Ukraine change over the years, and this leads to the emergence of new types of logistics to meet all subjects of logistics services. It has been determined that the development of warehouse logistics is influenced by both permanent and temporary factors. Permanent factors include political, economic and consumer factors. It is proved that the pandemic coronavirus disease (COVID-19) had a significant impact of temporary factors on the development of warehouse logistics in modern conditions. The temporary and permanent reasons for the development of warehouse logistics in Ukraine have been identified. The principles of warehouse logistics are presented. Tasks and levels of warehouse logistics are defined. The basic principles of warehouse logistics are given. These include: consistency, coordination and integration, optimization, sustainability and adaptability, cost reduction, TQM, the use of modeling and automation. It is proved that these principles of warehouse logistics allow to provide timely and quality services for storage, processing and shipment of inventory, provide interconnection of the warehouse with the services of supply, storage, transportation and shipment of inventory. It is proved that the decisive role in the management of warehouse logistics belongs to planning. The main objectives of integrated logistics planning include: the distribution of work areas and equipment on them, minimizing costs, increasing the level of cargo handling and warehouse capacity, increasing throughput capacity. Organizational and functional model of innovative transformation of regional transport and logistics systems, which together will contribute to the intensification of innovative development, engineering and re-engineering of warehouses and transport and logistics entities in general and the construction of modern logistics centers that provide high quality services using the latest technology, was substantiated.
\end{abstract}

Key words: organizational and functional model, transport and logistics systems, innovative transformations.

JEL Classification: F01, R14, Q28, Q29

\footnotetext{
Corresponding author:

${ }^{1}$ Admiral Makarov National University of Shipbuilding, Ukraine.

E-mail: innauamd@gmail.com

ORCID: https://orcid.org/0000-0002-7025-9857

${ }^{2}$ State Enterprise "Production Association Yuzhny Mashinbuilding Plant named after A.M. Makarov", Ukraine.

E-mail: management@nuos.edu.ua

ORCID: https://orcid.org/0000-0001-9566-3090

${ }^{3} \mathrm{CEO}$ at Movingcalifornia.com, Ukraine.

E-mail: management@nuos.edu.ua

ORCID: https://orcid.org/0000-0001-6225-5277
} 


\section{Introduction}

The post-industrial stage of development of the world economy and the gradual transition of most countries to the next stage, namely the information society, imposes its imprint on the forms, processes and means of creating competitive advantages and forms a new market reality, in which logistics have a significant role.

Modern warehouses are one of the most important integrative components of logistic lanes and are a complex technical structure that includes a number of interacting elements, which together provide the functions of processing, accumulation and distribution of goods between end users. Storage functions account for about $40 \%$ of the logistics costs of enterprises, so their optimization in accordance with the main global technological, informational and business trends is an important condition for business profitability and contributes to the creation of three interrelated competitive advantages, namely: speed of delivery of goods to the final consumer, safety of delivery and quality of goods, which depends on the peculiarities of their transportation and storage. Innovative technologies that are implemented in warehouse logistics are aimed at increasing the resulting competitive advantages, as well as ensuring economic and social security of the territories of distribution. That is why identifying the main innovative trends in the development of world warehouse logistics, their systematization and assessment of the main advantages is an important condition for the effective development of transport and logistics centers in Ukraine, including in the context of potential integration into the European and other transport and logistics systems.

With the globalization of the logistics market there is a need for Ukrainian companies to improve their activities, improve the quality of logistics services, to win new customers and expand its share. Economic indicators of the development of the logistics market in Ukraine have a positive trend. However, the influence of both internal and external factors on the variability is a component in assessing the effectiveness of warehouse logistics management. It has been researched that the majority of scientific works on assessing the effectiveness of management of warehouse logistics are carried out for a particular type of economic activity, since there are its own specifics. It has been established that when assessing the effectiveness of management of warehouse logistics, in addition to the system of indicators, the methodology and stages of their implementation are important. Therefore, the substantiation of the formation of the organizational and functional model of innovative transformation of transport and logistics systems is very relevant.

\section{Investigation of the content and system characteristics of the development of transport and logistics systems}

Of particular importance today is the development of logistics in Ukraine. The number of studies conducted in this subject area confirms this fact. However, the processes of globalization and instability associated with various factors increase the interest of scientists in determining the directions, trends in the development of logistics warehousing. To identify and improve the components of the development we consider it advisable to study the substantive and symbolic characteristics of logistics warehousing. This will allow to understand in more detail the essence of the concept and principles, factors and reasons for the formation of warehouse logistics in Ukraine.

The authors agree with the opinion of Burdyak O. M. and Kilipenko V. V. "Since logistics services for customers in the logistics market in Ukraine has not yet acquired sufficient development, and wholesalers in this market have no experience in organizing logistics, it is important to first bring the need for its use and identify key ways of creating and developing logistics systems in the industry" (Burdyak \& Kilipenko, 2010). Currently, there are significant gaps in the logistics market in Ukraine, which leads to delays in cargo shipments and losses of a significant number of customers. The unsatisfactory level of infrastructure forces business entities to look for new ways to deliver goods, and properly built warehouse logistics, in such circumstances, can be an alternative.

To disclose the essence and characteristics of the mechanism of development of warehouse logistics offer to explore the main theoretical approaches to defining the essence of the concept of "warehouse logistics"; disclose its principles; find the factors and causes of the formation of warehouse logistics in Ukraine.

In fact, warehouse logistics is closely related to transportation logistics; most scientists even study transportation and warehouse logistics itself as a complex system that completely satisfies suppliers through a closed logistics line.

Ivanishcheva A. V. also notes that "One of the new useful areas of logistics is intralogistics. Intralogistics or internal logistics is a term covering all products, components and processes related to the implementation, management, control and optimization of such internal production processes as storage, transportation and labeling of materials in the warehouses of industrial enterprises. In all of these areas, intralogistics is searching for non-universal, yet easily adaptable, technologies. Intralogistics also optimizes information flows between the various "logistics nodes" within an enterprise (e.g., production departments, distribution centers, etc.)" (Ivanishcheva, 
2016) It should be noted that modern conditions of logistics development require a corrective approach to the meaning of all its types. A significant number of researchers in their studies give preference to a completely closed logistics line "from supplier to customer or door to door". Indeed, this is a significant advantage for customers, but also a large set of problems that accompany this process. That is why today we are exploring internal logistics, the goal of which is to find problems in the internal logistics processes for each individual function.

However, over the years, the reasons and factors for the development of logistics in Ukraine are changing, which leads to the emergence of new types of logistics to meet all subjects of logistics services. Table 1 presents the main factors and motives for the development of logistics in Ukraine.

The authors agree with the opinion of Zaburanna L. V. (Zaburanna, 2010) that both permanent and temporary factors influence the development of logistics warehousing. The permanent ones include political, economic and environmental factors. In the current context of the coronavirus pandemic (COVID-19), it is possible to see the influence of temporary factors on the development of storage logistics. In fact, no one could have predicted the impact of the pandemic on the development of warehouse logistics not only in Ukraine, but even in developed countries. In fact, all countries were forced to close their borders, which delayed the depreciation of material values and the need to preserve them. And there were weaknesses in warehouse logistics: the lack of large storage facilities, weak logistical base, low level of infrastructure.

The author V. Katsma (Katsma, 2016) among the temporary and permanent factors influencing the spread of warehouse logistics in Ukraine, highlights both subjective and objective motives. Subjective motives require significant financial resources, namely the lack of state and regional programs for the development of warehouse logistics, the old material and technical base, inadequate infrastructure. For objective reasons, you need first of all the desire, and then the financial resources. In fact, the real reason for the development of warehouse logistics is the lack of highly qualified specialists in this field, even if due to the lack of highly qualified specialists in this field higher education institutions increase the number of applicants to this specialty, state-owned enterprises feel the pressure.

When characterizing warehouse logistics, it is important to consider its principles. The author believes that "Applying the principles of logistics management will allow the enterprise to ensure high competitiveness of its products and services by optimizing the costs associated with the production and sale of goods, accelerating the turnover of total capital, the fullest satisfaction of consumers in the quality of products and services. This effect is achieved by significantly reducing inventories of material resources and finished products in the areas of production, supply and sales, reducing the duration of the production cycle and the customer order fulfillment cycle. The introduction of flexible automated and

Table 1

The main factors and motives for the operation of warehouse logistics in Ukraine

\begin{tabular}{|l|l|}
\hline \multicolumn{1}{|c|}{ Causes } & \multicolumn{1}{c|}{ Main content } \\
\hline Time factors & This is due to both the transitional nature of the Ukrainian system of government and the longer period. \\
\hline Ongoing factors & $\begin{array}{l}\text { Size and geographic location of the country; type, amount, quality and availability of natural resources; availability of } \\
\text { intellectual potential and qualified labor resources; size, specialization and distribution of industrial complexes and } \\
\text { centers across the country; level of integration into the world economic space. }\end{array}$ \\
\hline $\begin{array}{l}\text { Imperfection of methodological foundations for the introduction of logistics in the real sector of Ukraine's economy; } \\
\text { lack of awareness of logistics interfaces in existing state systems; unstable legal field of business entities, as well as } \\
\text { ill-conceived taxation system; lack of necessary structuring of business systems required for the implementation of } \\
\text { logistics; significant obsolescence and physical deterioration of production equipment; underdeveloped transport } \\
\text { infrastructure that does not meet modern requirements (high level of physical and moral wear of vehicles and, } \\
\text { consequently, low efficiency of their functioning); low level of development of production and technical base of } \\
\text { warehousing; low level of development and use of modern systems of electronic communications, electronic networks, } \\
\text { communication and telecommunication systems. }\end{array}$ \\
\hline Subjective reasons \\
$\begin{array}{l}\text { Lack of qualified specialists in the field of logistics and the potential unwillingness of managers to change work } \\
\text { stereotypes based on a general low legal and managerial culture. Supply, delivery and sales managers, who are used to } \\
\text { performing their traditional functions, inhibit the introduction of a branched out scheme of managing the material } \\
\text { flows of the company, because the goals of logistics do not correspond to the goals of individual functional units. } \\
\text { Moreover, an individual enterprise optimized in terms of logistics may not be optimal in the overall logistics balance } \\
\text { due to the fact that the logistics approach involves the production company and its related suppliers, intermediaries } \\
\text { and customers indirectly involved in the workload. The coordination of a logistics team consisting of different } \\
\text { companies is the most important when using logistics management methods. }\end{array}$ \\
\hline
\end{tabular}

Source: compiled by authors (Zaburanna, 2010; Katsma, 2016) 


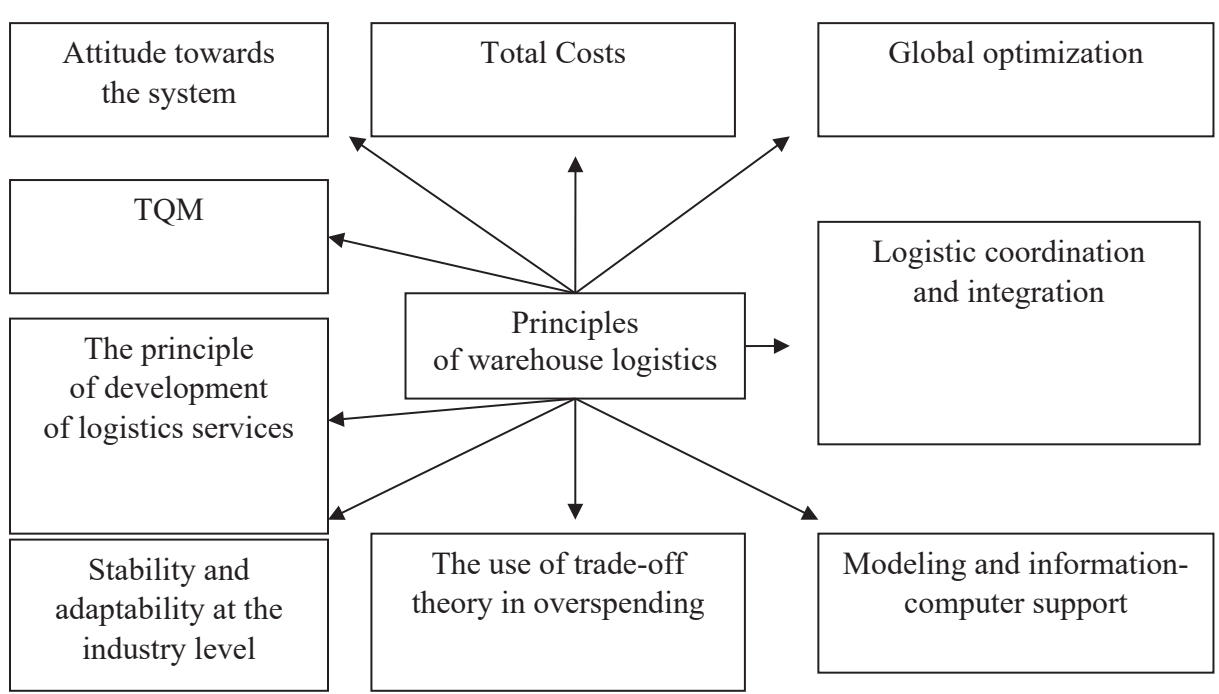

Figure 1. Principles of warehouse logistics

Source: compiled by the author into the main: (Melnik, 2013)

robotic production, allowing rapid transition to the production of new types of products, the creation of marketing channels, etc" (Katsma, 2016). The paper agrees with the author's opinion, the need to implement all the principles of warehouse logistics will allow for meaningful and high-quality logistics services. Figure 1 shows the principles of warehouse logistics.

Among the main principles of warehouse logistics: consistency, coordination and integration, optimization, sustainability and adaptability, cost reduction, TQM, use of modeling and automation. These principles of warehouse logistics enable the smooth and accurate provision of storage, handling and disposal services, ensuring that warehouse operations are interconnected with the services involved in the supply, storage, transportation and shipment of inventory.

It is important to determine the main task and level of warehouse logistics (Figure 2).

So, the main task of logistics is to manage the logistics of warehousing. Also Kornietsky O. V. (Kornietsky, 2012) distinguishes three levels of logistics management, they function depending on the volume of logistics services. In our opinion, it is advisable to reduce the number of levels to a simple value, which we propose to do in the next paragraph, this will highlight the logistics functions separately for the subjects of the logistics process.

Leonova Y. O. also notes that "The logistical process in the warehouse requires full synchronization of work in the areas of inventory supply, processing, and actual processing of vantage distribution of orders. Logistics in the warehouse practically covers all the main working areas, which are considered at the micro level. The logistics process is much broader than the technological process and includes such areas as: ensuring supplies, supply control, receiving and unloading of defects, transportation and internal processing of defects, warehousing and storage of defects, formation of customer orders and defects, forwarding and transportation of defects. The work of all elements of the logistics process must be considered in interdependence and interconnection" (Leonova, 2012).

\section{Formation of organizational and functional model of innovative transformation of transport and logistics systems}

Ensuring compliance of domestic warehouse logistics and bringing it to a global level of quality requires improving primarily the state and regional policies on investment and innovation, creating conditions for attracting foreign investment and unimpeded transfer of technology, effective mechanisms of state guarantee and protection of innovation, further development of public-private partnerships and the development of the stock market. Equally important is the continuation of the movement toward the introduction of European standards and norms in logistics, the simplification of conditions for crossing the customs border, and the fight against corruption.

The authors agree with Kopishinska $\mathrm{K}$. that the active introduction of innovations in the field of logistics in enterprises requires the support and creation of appropriate conditions at the highest levels, including international, national, regional and industry. Figure 3 presents the main objectives of logistics management at the meta-, macro- and meso-levels, the implementation of which will facilitate the active implementation of modern innovative trends in the 


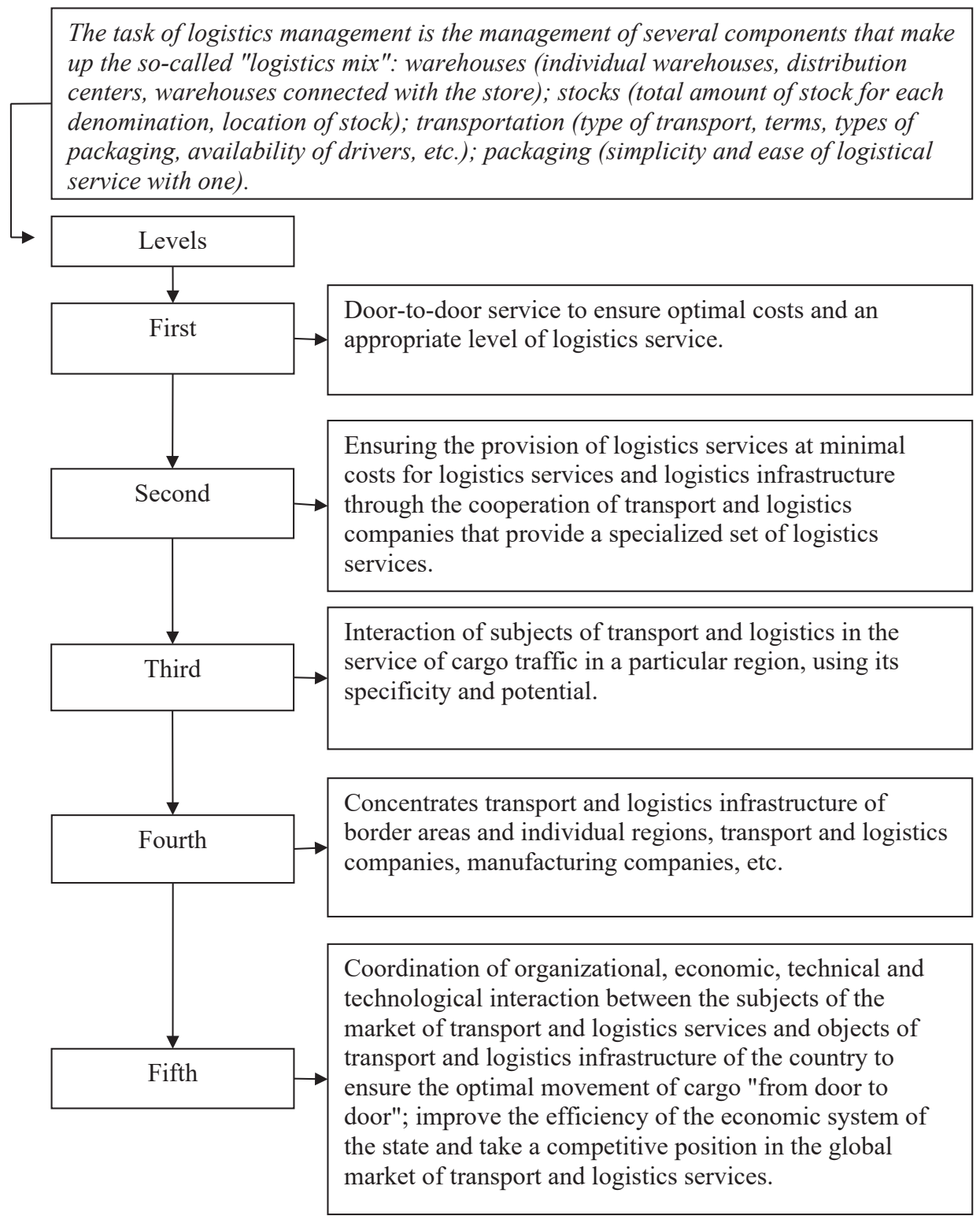

Figure 2. Tasks and levels of warehouse logistics

Source: compiled by author (Kornietsky, 2015)

development of transport and logistics companies in Ukraine.

The figure shows the distribution of functions and priorities, the system implementation of which will contribute to the innovative development, engineering and re-engineering of warehouses and transport and logistics entities in general and the construction of modern logistics centers that provide high quality services using the latest technology.

Modern organizational trends in the development of warehouse logistics can also include the transition of logistics operators to comprehensive services that can be offered to customers. Ukraine is currently undergoing a gradual transformation of logistics operators from the freight transport system to the expansion of service, in particular, using digital technology. Table 2 shows the main characteristics of logistics operators in Ukraine by level of transport and logistics services.

The data in the table shows that logistics activities in Ukraine are gradually developing, there are operators who improve business processes and offer a wider range of logistics services, and competition is increasing. At the same time, the market potential of transport and logistics systems in the context of transformational processes taking place in the economy, geopolitics and social sphere is significant and requires more active innovative transformations.

The development of warehouse logistics in the regions involves the introduction of organizational innovations 

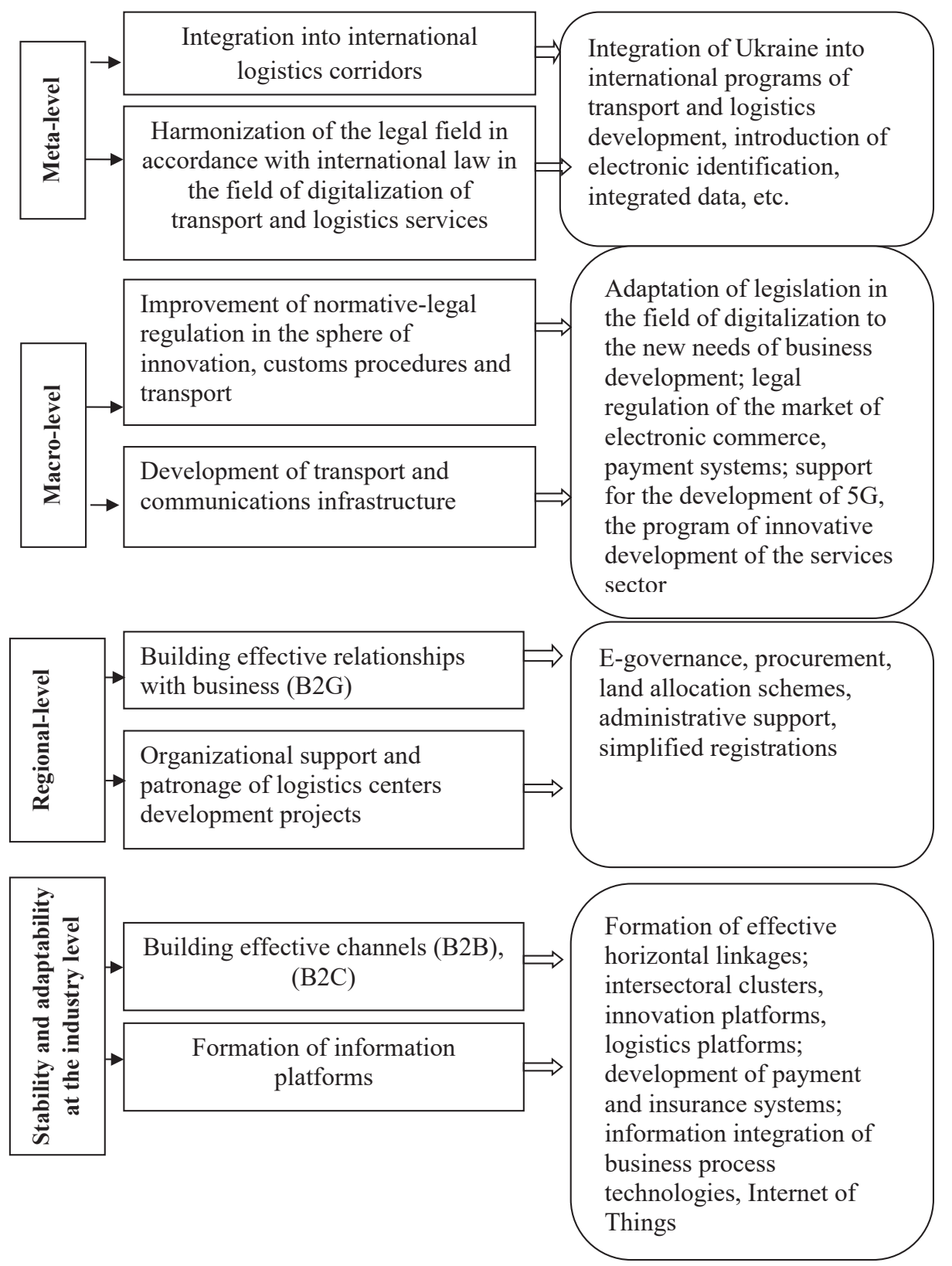

Figure 3. Organizational and functional model of innovative transformation of regional transport and logistics systems

Source: systematized by the authors

that require the integration and coordination of the efforts of local authorities, businesses and government support. In this context, it is worth referring to the experience of developed economies, where organizational innovations in the field of transport and logistics are an important tool for ensuring the competitive advantages of regions and individual territories.

Transport and logistics centers are important organizational formations, tied to separate territories and serving to ensure the smooth delivery of goods, information and financial flows between economic entities. According to Kirlik N. Yu, "In European countries transport and logistics centers are quite
Integration of Ukraine into international programs of transport and logistics development, introduction of electronic identification, integrated data, etc.

\section{Adaptation of legislation in} the field of digitalization to the new needs of business development; legal regulation of the market of electronic commerce, payment systems; support for the development of $5 \mathrm{G}$, the program of innovative development of the services

land allocation schemes, administrative support, simplified registrations gistics platforms; formation integration of ess technologies, Internet of Things 
Table 2

Levels of logistics services in Ukraine

\begin{tabular}{|l|l|l|l|}
\hline Level & \multicolumn{1}{|c|}{ Name } & \multicolumn{1}{c|}{ Characteristic } & \multicolumn{1}{c|}{$\begin{array}{c}\text { Name of companies in } \\
\text { Ukraine }\end{array}$} \\
\hline $\mathbf{1 P L}$ & $\begin{array}{l}\text { Logistics } \\
\text { Insourcing }\end{array}$ & $\begin{array}{l}\text { A type of logistics service where all logistics processes are carried out directly } \\
\text { by the company's own carrier on its own transport, i.e., the entire logistics of the } \\
\text { enterprise is autonomous. }\end{array}$ & $\begin{array}{l}\text { The vast majority of domestic } \\
\text { enterprises }\end{array}$ \\
\hline 2PL & $\begin{array}{l}\text { Partial logistics } \\
\text { outsourcing }\end{array}$ & $\begin{array}{l}\text { Type of logistics activities when warehousing, transportation occurs with the } \\
\text { involvement of third-party companies, but the management of the supply chain } \\
\text { is carried out independently. At the present stage in Ukraine, most companies } \\
\text { prefer this type of logistics services. }\end{array}$ & $\begin{array}{l}\text { Intime, Delivery, Nova } \\
\text { Poshta, MistExpress }\end{array}$ \\
\hline 3PL & $\begin{array}{l}\text { Comprehensive } \\
\text { logistics } \\
\text { outsourcing }\end{array}$ & $\begin{array}{l}\text { 3PL providers are multidisciplinary logistics providers with highly professional } \\
\text { personnel. They are engaged in the delivery of goods, customs clearance, } \\
\text { packaging, packing of goods, etc. }\end{array}$ & $\begin{array}{l}\text { Grand Logistics, UVK, DHL, } \\
\text { NEOLIT, Black Sea Shipping } \\
\text { Service Ltd. }\end{array}$ \\
\hline 4PL & $\begin{array}{l}\text { Integrated } \\
\text { logistics } \\
\text { outsourcing }\end{array}$ & $\begin{array}{l}\text { Type of logistics service when a client company not only hires an outsourcer to } \\
\text { perform transportation logistics functions, but also delegates him the tasks of } \\
\text { designing and managing supply chains and logistics business processes at the } \\
\text { enterprise. }\end{array}$ & $\begin{array}{l}\text { Metro Cash \& Carry - } \\
\text { METRO MGL Logistik } \\
\text { GmbH }\end{array}$ \\
\hline 5PL & $\begin{array}{l}\text { Virtual logistics } \\
\text { Logistics service, which covers the entire range of logistics services of the global } \\
\text { information technology space. }\end{array}$ & $\begin{array}{l}\text { Transnational 4PL and 5PL } \\
\text { providers }\end{array}$ \\
\hline
\end{tabular}

and investing in the development of transport and logistics infrastructure depend on the economic characteristics of the territory, its geographical location, the prevailing types of business. However, the creation of transport centers, hubs of freight villages and other forms of territorial logistics is recognized as one of the priorities of spatial development and an important component of competitive development.

As noted by Tkach O. V. and Voloshchuk I. A. "A promising area for cooperation in the development of euro-logistics is the attraction of additional volumes of transit cargo flows through the customs territory of Ukraine. It is advisable to concentrate terminals, warehouses, transshipment complexes and other transport infrastructure necessary for comprehensive processing under customs control of significant volumes of export-import and transit cargo within the checkpoint in Ukraine. efficiency of the use of transit potential" (Tkach \& Voloshchuk, 2014).

In this context, regional authorities should be interested in creating so-called transport and logistics centers in each region, especially in areas where major transport hubs are concentrated. "Transportation and logistics centers / freight villages", as defined by the Europlatform Association, "are certain infrastructures that are equipped with all public facilities to provide a range of services related to all types of transportation activities. The Freight Village is a specific region of the country within which various market operators provide a full range of services related to the transportation and logistics distribution of goods for both compatriots and international transit" (Bonyar \& Korniyko, 2012).
In Ukraine, logistics centers are not distinguished as separate objects of transport and logistics infrastructure, but in most cases are identified with a set of professional warehouses, distribution centers, terminals, etc. The lack of well-established economic ties, unified software, and the diversity of terminal and space owners create barriers to active innovation and competition within the facilities themselves. In addition, the majority of transport and logistics centers (70\%) are concentrated in Kiev and large cities (Odessa, Lviv, Kharkiv, Dnipro and partially Mykolaiv). In the regions, logistics operators work mainly locally, trying to serve existing logistics chains in accordance with the contracts concluded.

The authors agree with the opinion of Gritsina L. A. and Harun O. A., "New market requirements can be met by creating a system of transport and logistics centers, which minimize logistics costs and increase the efficiency of business entities. However, in world practice, two basic approaches to the development of transport and logistics infrastructure, which can be conventionally called the European and American. The first involves an active public policy aimed at improving the efficiency of freight transport and the development of logistics centers by providing tax incentives, government subsidies or grants. The second approach is based on the mechanism of market regulation of the logistics sector, which minimizes the need for government intervention and encourages private companies and investors to invest in the development of logistics infrastructure" (Gritsina \& Harun, 2019). 
The study shows that the introduction of major innovative directions in the development of regional logistics systems is not only a prerequisite for the competitiveness of domestic logistics operators, but also the regional economy and the national economy as a whole, as it significantly reduces the logistics costs of all economic entities. and manageability of logistics processes, increasing the economic and food security of the region.

During the transformation of Ukraine's economy based on market relations, considerable attention was paid to the study of food security issues of the country as a whole (Irtyshcheva, Ponomarova \& Dolzhykova, 2019). The system of interconnections determines the necessity of detailed assessment of infrastructure elements in order to find and substantiate the directions of formation of effective levers of influence on the development of agricultural products market with regard to globalization transformations (Vyshnevska, Kaliuzhna \& Irtyshcheva, 2019).

Despite the assertion that the development of warehouse logistics is primarily a business problem, state and regional policies in the field of transport, logistics, innovation and investment have a significant impact on the development and innovative development of warehouse systems. That is why mechanisms are being developed to introduce international standards and norms in the field of customs control, technical and service standards, information security, technology transfer and other regulatory documents, their unification with those in force in the EU, which will accelerate the integration of transport and logistics systems and facilitate the rapid introduction of innovation.

At the regional level, important tasks are to build effective communications with representatives of business, simplify and optimize regulatory activity, improve the business climate and develop mechanisms to encourage investment in the development of transport and logistics systems, especially in depressed areas.

Thus, the improvement of financial mechanism of socially-oriented development model requires a comprehensive justification and establishment of clear and transparent financial relations in the areas of formation of revenues and allocation of costs of regional budgets at all levels, creating conditions for additional attraction of financial resources from extrabudgetary sources aimed at the implementation of regional social programs, and the creation of an effective system for monitoring the functioning of the financial mechanism, primarily on the part of territorial communities (Stehnei, Irtyshcheva \& Gurina, 2018).

\section{Conclusions}

The main factors and reasons for the development of warehouse logistics in Ukraine were revealed. It has been proved that the reasons and factors for the development of logistics in Ukraine change over the years, and this leads to the emergence of new types of logistics to meet all subjects of logistics services. It has been determined that the development of warehouse logistics is influenced by both permanent and temporary factors. Permanent factors include political, economic and consumer factors. It is proved that the pandemic coronavirus disease (COVID-19) had a significant impact of temporary factors on the development of warehouse logistics in modern conditions. The temporary and permanent reasons for the development of warehouse logistics in Ukraine have been identified.

The basic principles of warehouse logistics are presented. They include: consistency, coordination and integration, optimization, sustainability and adaptability, cost reduction, TQM, application of modeling and automation. It is proved that these principles of warehouse logistics allow to provide timely and quality services for storage, processing and shipment of inventory, provide interconnection of the warehouse with the services of supply, storage, transportation and shipment of inventory. It has been proven that the decisive role in warehouse logistics management belongs to planning. The main tasks of integrated logistics planning include: distribution of work areas and equipment on them, cost minimization, increasing the level of cargo handling and warehouse capacity, increasing throughput capacity.

Organizational and functional model of innovative transformation of regional transport and logistics systems, which together will contribute to the intensification of innovative development, engineering and re-engineering of warehouses and transport and logistics entities in general and the construction of modern logistics centers that provide high quality services using the latest technology, was substantiated.

\section{References:}

Burdyak, O. M., \& Kilipenko, V. V. Warehouse logistics in the field of logistics of agro-industrial complex. Available at: http://www.chtei-knteu.cv.ua/herald/content/download/archive/2010/v4/NV-2010-V4_39.pdf (accessed 15.04.2021);

Ivanishcheva, A. V. (2016). Modern directions of development of logistics technologies in Ukraine. Market economy: modern theory and practice of management, 15, 3(34), 96-115.

Zaburanna, L. V. (2010). Logistic management of the enterprise: the essence and prerequisites for development. Sustainable economic development, 7, 120-123. 
Katsma, V. I. (2016). The essence and role of logistics management in the enterprise management system. Economic analysis: coll. science. work, 23.2, 60-65.

Melnik, O. V. (2013). New conceptual approaches in logistics. Efficient economy, 2. Available at: http://www.economy.nayka.com.ua (accessed April 15, 2021).

Transport and logistics centers: foreign experience (2021). Available at: http://www.mainw.elc!Ua.com/ru/ news $/ 60$

Kornietsky, O. V. (2015). The concept and essence of logistics. Agrosvit, 14, 13-16.

Leonova, Y. O. (2012). Optimization of warehousing activities of LLC "FIDLIFE". Business information, 7, 88-91. Khrutba, Yu. S., Paranich, P. G., \& Idziev, T. B. (2020). The current state and features of the development of the logistics services market in Ukraine. The current state of research and technology in industry, 4(14), 129-136.

Irtyshcheva, I., Ponomarova, M., \& Dolzhykova, I. (2019). Conceptual fundamentals of development of the food security system. Baltic Journal of Economic Studies, 5(2), 57-64.

Khrutba, Yu. S., Paranich, P. G., \& Idziev, T. B. (2020). Current state and features of the market of logistics services in Ukraine. The current state of research and technology in industry, 4(14), 129-136.

Kirlik, N. Yu. (2016). formation of a single logistics system: an important component of European integration processes. Scientific Bulletin of the International Humanities University. Series: Economics and Management, 22, 98-101. Weaver, O. V., \& Voloshchuk I. A. (2014). Formation of a unified logistics system: an important component of European integration processes. Scientific Bulletin of Kherson State University, 9(1), 208-212.

Bonyar, S. M., \& Korniyko, J. R. (2012). International experience in creating multimodal transport and logistics centers. Economy and state, 3, 32-35.

Stehnei, M., Irtyshcheva, I., \& Gurina, O. (2018). Financial mechanism of the socio-oriented economic development of the black sea region. Baltic Journal of Economic Studies, 4, 202-208. DOI: https://doi.org/ 10.30525/2256-0742/2018-4-4-202-208

Vyshnevska, O., Kaliuzhna, O., \& Irtyshcheva, I. (2019). Infrastructure provision of the agrarian market in the globalized environment. Baltic Journal of Economic Studies, 5(5), 39-46. DOI: https://doi.org/10.30525/22560742/2019-5-5-39-46

Gritsina, L. A., \& Harun, O. A. (2019). Comparative analysis of the development of transport and logistics systems of leading countries. Bulletin of Khmelnytsky National University, 2, 143-146. 